\title{
Tourism, Religion and Religiosity: A Holy Mess
}

\author{
Yaniv Poria \\ Ben-Gurion University of the Negev, Beer-Sheva, Israel \\ Richard Butler and David Airey \\ University of Surrey, Guildford, England
}

\begin{abstract}
Although religion and religiosity are well-known factors for influencing behaviour in different social settings, there is very limited research that explores the links between them and visitation patterns of tourists. In this study tourists' visitation patterns to a heritage site of religious significance (the Wailing Wall, Israel) are explored. Differences are found between tourists based on their religious affiliation and religiosity. The findings also reveal that the tourists' religiosity has different effects on those with different religious affiliations. It is argued that the actual relationships between a tourist's religion and strength of religious belief need to be understood in relation to the site visited, the tourist's perception of it and the meaning he or she attaches to it. The implications for tourism management and the theoretical investigation of heritage tourism are discussed.
\end{abstract}

Keywords: Religion, religiosity, tourism, perception, heritage, Israel

\section{Introduction}

The current situation in the Middle East as well as the Twin Towers disaster of 2001 in New York highlights the key role that religion plays in our world. However, religion is not only a factor of importance for understanding conflict between nations but also in people's daily activities. There is much literature to suggest that religion is a fundamental element of our culture and is linked to many aspects of our life and behaviour (Bailey \& Sood, 1993; Krausz, 1972; Lupfer \& Wald, 1985; Lupfer et al., 1992; McDaniel \& Burnett, 1990; Walter, 2002; Wilkes et al., 1986). Evidence for links between religion and behaviour can be found in activities that form part of an individual's daily routines, as well as in those rituals that are rare and unique. Similarly, evidence for the influence of religion on behaviour is found in areas such as parental attachment, clothing styles, eating and drinking, the use of cosmetics, social and political views and sexual behaviour (Hood \& Morris, 1985; Levin, 1979; Poulson et al., 1998). Clearly the motives for participating in religious experiences are linked to religion (Gorlow \& Schroeder, 1968).

The effects of religious belief on behaviour emanate from two main sources (McDaniel \& Burnett, 1990; Wilkes et al.,1986). First, there are the taboos and obligations which people who belong to and follow a certain religion have to practise. Examples include the religious rules forbidding Jewish and Muslim believers to eat pork, or Hindus to eat cows. The second way behaviour is affected is associated with the fact that religion contributes to the formation of culture, attitudes and values in society (McClain, 1979). This also affects those who do not practise any religion or do not believe in the existence of a god (Bailey 
\& Sood, 1993; Elboim-Dror, 1994; Hirschman, 1981; Waters et al., 1975). Such influences can be seen to be linked to mundane activities that are not mentioned in the holy books often used by religious people as a guide for their daily life. For example, a body of research has demonstrated differences in certain value systems based on an individual's religious 'belonging' (e.g. Rokeach, 1969). Here religion is perceived to be a factor that influences someone's environment, where such influences are not linked to an individual's strength of religious belief. Aspects of life affected by such religious 'belonging' could include academic studies (Lehman \& Shriver, 1968) or perception of actions as good and evil (De Jong et al., 1976).

Religion, whether working through taboos and obligation or through its influence on the culture and society, is known to affect our behaviour as consumers (Delener, 1990; McDaniel \& Burnett, 1990; Wilkes et al., 1986;Zaichkowsky \& Sood, 1989). The literature provides evidence that people's religion and religiosity will influence their consumption habits (Grigg, 1995). An example of the influence of religion on the individual is provided by Hirshman (1981). She has looked at Jewish people without referring to individual strength of religious belief, and suggests that information gathering and the will to adopt new products are higher among Jews than among those of other faiths. In her research she proposes that this pattern is associated with high exposure to information and high levels of self-education in Jewish families. Sood and Nasu (1995) provided some evidence that a person's religiosity influences his or her behaviour. They found that devout Protestants were more concerned with prices, considering products from other countries and patronising retail stores than non-devout Protestants.

Religion is also linked to tourism, in terms of both consumer (tourist) behaviour and the supplier (host), as well as the relationship between them. However, a very limited body of research is available dealing with these concepts, a fact that seems surprising given the links between the history of tourism and that of religion (Howe, 2001; Rinschede, 1992).

The structure of this paper is as follows. In the literature review, two issues are covered. First, former studies concerned with religion in the context of tourism are reviewed and then the location of the study is considered. The research objectives are then presented, followed by the methodological framework. Finally, the findings and the conclusions are presented.

\section{Literature Review}

\section{The place of religion in tourism research}

Religion as a concept is linked to a variety of issues in the tourism research literature, but is most commonly mentioned in relation to pilgrimage and discussions about the links between tourism and pilgrimage (Cohen, 1992a, 1992b, 1998; Din, 1989; Fleischer, 2000; Hitrec, 1990; Joseph \& Kavoori, 2001;Rinschede, 1992; Smith, 1992; Turner, 1973). Sousa (1988) for example, suggests that the acts of travel described in the Old and New Testaments, whether it is Jesus travelling in the land of Israel or the travels of the Jewish people to discover their god, should be approached as a form of tourism. Shackley (2002) provides an example of how the boundaries of religion can be drawn widely in the example of the prison that housed Nelson Mandela for almost 20 years in Robben Island. This, 
she suggests, is seen as 'a sacred site and a shrine to a living man' (p. 355). It is suggested here that, in tourism research, religion is associated with three main areas: research concerning the supply of tourism, research concerning the link between religion and tourism on a more theoretical level, and research exploring tourist behaviour.

Religion was found to be a factor linked to the supply of tourism on both a macro and micro level. An example of influence on the macro level is provided by Israeli and Mehrez (2000), who associated the approach towards gambling and its future provision for tourists in Israel with the fact that there is no division between state and religion in that country. On the micro level, Brown (1996) in his ethnographic study of the 'Borscht Belt', provides evidence of how religious taboos influence the provision of hotel services, such as the variety of food ingredients and the service procedures.

Another area of research has linked religion to the relationship between the tourists (the guests) and the local community (the hosts) or the site. Din (1989) suggests that a difference between the religion of the host and the guest may influence the service supplied to the guest in certain Muslim countries. Din also argues in this context that, due to certain religious beliefs, tourism is discouraged in some Muslim countries because of its impact on the local community. Joseph and Kavoori (2001) suggest that tourism being seen as a threat by a local community is linked to its perceived influence on local traditions, including religious habits. Based on their study in Nazareth, Uriely et al. (2000) also suggest that local people's approach to a tourist attraction may be influenced by their religion. Brunet et al. (2001) regard the possible influence of tourism on local religion as a factor that should be taken into account in the development of sustainable tourism in Bhutan. Shackley (1999), in her research about tourism development and environmental protection in southern Sinai, suggests that the monastery of St Katherine may suffer damage because of the presence of tourists.

It is also common to view religious artefacts or customs (e.g. monuments, ceremonies) as a resource to attract tourists (Shackley, 2001). In their study of the development of tourism in Bhutan, Brunet et al. (2001) see the cultural traditions, the local religion and the religious festivals as some of the main factors with potential to attract tourists. Religion is also mentioned in the literature in relation to the way tourist attractions are presented and interpreted, i.e. how it is used to promote a site or promote an ideological framework or certain view. An example of this is provided by Worden (2001) who investigated how heritage was represented in Malaysia and suggested that the presentation of religious history in that country was manipulated to represent the current approach to Islam there.

Another stream of research involves those studies that investigate the relationship between religion and tourism on a theoretical level as a social phenomenon (Cohen, 1992a, 1992b). Much of this research looks at the links and differences between pilgrims and tourists (Cohen, 1992b; MacCannell, 1973). Knight (1996), for example, considers the concept of religion (for guests and host) in relation to rural tourism in Japan, and sees it as a relevant factor in explaining individuals' perceptions of tourism and tourists. Srisang (1985) suggests that tourism could be viewed as a form of religious social behaviour even when the tourists are not searching for their god but looking for a certain truth. Cohen's 
(1992a) research looks at tourism and religion, focusing on the nature of these two phenomena and the relationship between them based on structural analysis, phenomenal analysis and institutional analysis.

Another branch of research relates to people's religion as a factor that explains their behaviour as tourists, whether it acts as a motivating force, a constraint, or in relation to aspects of the tourists' visitation patterns themselves. Fleischer and Pizam (2002) looked at constraints affecting the participation of seniors in vacation activities. They emphasised the effect of a tourist's religious affiliation as a possible constraint. For example, they observed that 'Jews do not travel on Saturdays and other Jewish holidays' (p.114). Evidence for the place of religion as a motivation for tourist activities linked to pilgrimage is commonly given (Constable, 1976; Smith, 1992). Jackson and Hudman (1995) studied visitation patterns to cathedrals in England. Although religion was not found to be a motivating factor for the travel as a whole, it was found to be a motivation for the visit to a cathedral during the travel. Mansfeld (1995), in his research concerning the north-west London Jewish community, suggests that a tourist's religion is associated with belonging to a certain social reference group which may influence the behaviour of the tourist. Fleischer (2000), in her study about pilgrims to the Holy Land, suggests that those tourists who regard themselves as pilgrims have different personal characteristics and visitation patterns from other tourists visiting Israel. She compared tourists based on their religious affiliation and suggested differences between Protestants and Catholics in terms of their perception of the visit as sacred or secular.

Mattila et al. (2001) found relationships between student behaviour while on spring vacation and their religion. Among those students who considered themselves part of a certain religion, drug use and casual sex was less common than among those who did not.

Although, from what has already been stated, religion is linked to tourist behaviour, two issues are worth mentioning at this stage, as they are important for this study in particular. First, it is rare for studies to focus on tourists' strength of religious belief. Second, it is common for studies to be concerned with specific aspects of a visit alone, without investigating behaviour before, during and after the visit. Also, in this context, it is rare for comparisons to be made between groups with different religious affiliations.

\section{The location of the study}

Some religious places are well known also as tourist attractions (Cohen, 1998; Jackson \& Hudman, 1995; Joseph \& Kavoori, 2001; Smith, 1992). It is recognised by different scholars that such places are visited for different reasons, such as their architecture, appearance and historical importance, some of which have nothing to do with religion directly. For example, Knight (1996) suggested that the forest in his study, although classified as a pilgrimage site, attracts people for different reasons, some of which have nothing to do with religion (e.g. pleasure and relaxation). This study aims to investigate the relationships between tourists' visitation patterns, their religious affiliation and their strength of religious belief. As such, the site to be chosen needs to have a 'religious' connection that attracts people from different religions with a range of strengths of religious 
belief. Such diversity is essential for a meaningful investigation of the research problem.

This research is based on a study about the Wailing Wall in Jerusalem, Israel. The Middle East in general and Israel in particular are already recognised as tourist attractions linked to the origins of the three great monotheistic religions (Alavi \& Yasin, 2000; Rinschede, 1992; Sousa, 1988; Uriely et al., 2000). The rationale for choosing this specific site centred on its unique attributes. First, the site, at its core, presents historic artefacts and religious ritual (the wall itself and the people praying). There are no other facilities or elements that attract tourists to the site or may influence the tourists' experience of the visit. Second, based on data gathered by the Israel Ministry of Tourism, the Wailing Wall is the most popular site in Israel (Israel Ministry of Tourism, 1996, 1997, 1998) and attracts the diversity of tourists essential for the current research. Third, no entrance fee is required for the site and entrance is open to all. These factors have major implications, as other sites in Jerusalem could have been chosen for the study (e.g. El-Aqsa Mosque) but were eliminated because the absence of such factors would have minimised the diversity required.

Jerusalem has been a centre of pilgrimage since the evolution of the monotheistic religions, especially among Christian and Jewish people. Some perceive this religious journeying to be the first form of tourism (Favreau-Lilie, 1995; Rinschede, 1992; Shoval \& Cohen-Hattab, 2001; Smith, 1992). Evidence for the importance of Jerusalem as a tourist attraction dates back to 333 ВC when the oldest known guidebook was published, entitled Itinerary from Bordeaux to Jerusalem (Sigaux, 1966). The Wailing Wall itself is located in Jerusalem and is considered to be the only remaining part of the Temple destroyed in $70 \mathrm{AD}$ after the encounter between Jewish rebels and Roman siege forces, which explains its importance for Jewish people today (Silberman, 2001).

In addition, the Temple area and the Wailing Wall hosted some of the most important events in Jesus' life, as recounted in the New Testament. Forty days after his birth Jesus was brought to the Temple and Simeon prophesied that he would cause 'the fall and rising again of many in Israel' (Luke 2: 34). Later, when Jesus was twelve years old, he came with his parents to the Temple and there the people were 'astonished at his understanding and answers' (Luke 2: 47). Another visit to the Temple is described in John's Gospel (8: 111), when a woman caught in the act of adultery was brought before Jesus. Although the laws at that time prescribed stoning for her offence, Jesus merely stated 'he that is without sin among you, let him first cast a stone at her'. The high point of his activities in the Temple area took place on his last journey to Jerusalem (Schiller, 1992) documented in Mark (11:15-17). At this point Jesus confronted the activities and social happenings in the Temple area. These two acts were political and philosophical statements, as Jesus was acting against the former law, based on the Old Testament, in the heart of the Holy Land in Jerusalem. Although these activities and others all took place in the Temple area, it did not become a formal pilgrimage site and is not officially considered as holy by the Christian church. One reason for this is that the area became holy for Muslims and Christians were not allowed to visit it when Muslims controlled Jerusalem (Schiller, 1992).

The Wailing Wall is perceived by religious Jews to be the most important place 
on earth, being the only remainder of the Temple where ancient Jews worshipped their god. Currently the Wailing Wall has enormous significance in the Zionist State of Israel. Its importance is associated with its symbolising Jewish independence, and the way it was managed and treated during the time the Arabs controlled Jerusalem (until 1967). During this period, the Wailing Wall was used in a way that Jewish people perceived as not respecting its special nature (for example, sometimes people would cut their hair and beards there). The number of people allowed to enter the site was also controlled during this time and their freedom to practise their religion curtailed. Such restrictions have made the site a symbol for Zionists following its liberation (Aner et al., 1981). In fact, for the Jewish people, the liberation of the Wailing Wall during the Six Days' War symbolised that finally, after 2000 years of diaspora, the Jews had gained independence in their homeland.

The importance of the Wailing Wall to the state of Israel as a whole can be illustrated by the fact that some of its important formal ceremonies take place in the area, and Israeli army units use its esplanade for swearing-in ceremonies (Eber \& O'Sullivan, 1989). Further evidence of its importance can be seen in the recent attempt of a Muslim terrorist from the El-Qaida group to bomb the Wailing Wall area (Maariv, 2002).

\section{The Research Objective: Does a Tourist's Religion or Strength of Religious Belief Influence their Experience at the Wailing Wall Site?}

Tourist attractions where religious historic artefacts are presented are often regarded and approached as heritage attractions in the tourism literature. Murray and Graham (1997), for example, suggested that the Camino de Santiago can be seen as a 'heritage complex' (1997: 515). It is known that heritage attractions are perceived differently by different people and are visited for various reasons such as their appearance (Russo, 2002) or the meaning visitors attach to them (Henderson, 2002; Teo \& Huang, 1995). The Wailing Wall is regarded here as a heritage site (Nuryanti, 1996), as it is a historic construction of great importance to the monotheistic religions in general, and is the most important site for Jewish people in particular.

This research relies on the reasoning discussed in the tourism literature that understanding of a tourist's experience of a site should be seen in relation to the links between the tourist and the site. More specifically, in the context of heritage tourism this experience should be based on a tourist's perception of the site in relation to his or her own heritage (Poria, 2001; Poria et al., 2001a, 2001b, 2003a). The present research aims to determine whether the actual perceptions of the Wailing Wall, as well as aspects of the visit, are linked to tourists' religious affiliation and strength of religious belief. This investigation is part of a larger study aimed at exploring tourists' visitation patterns to heritage places. It is important to state at this point that it is not claimed that any relationship described here between the tourists' religion and their strength of religious belief is the core reason for their tourist behaviour but rather a hint towards its understanding. Nevertheless, it is suggested that the present findings are an example of the place of religion and religiosity in affecting tourist behaviour. 
It is argued that the data presented will help to clarify aspects that have received almost no attention in the tourism literature to date, namely the place of tourists' religion and their strength of religious belief in their tourist experience. The current research may also have implications for the management of attractions presenting heritage/religious artefacts, as well as for the theoretical investigation of tourism as a social phenomenon.

\section{Methodological Framework}

The methodological framework has already been described in former studies (Poria, 2001; Poria et al., 2003a). Those elements relevant for the purpose of this research are further summarised below.

As the main aim of this research was to identify the tourists' personal characteristics, including their religion and strength of religious belief, as well as to determine their visitation patterns (all of which are elements that can be measured), a quantitative research approach was used (Ragin, 1994). It was decided to collect the data at Ben-Gurion Airport (Tel Aviv) at the end of the tourists' visits to Israel for two main reasons. First, at this point, the tourists' memories of their experiences were fresh. And second, the majority of tourists visiting Israel leave from Ben-Gurion Airport, making it a good location for capturing a diverse range of visitors (Israel Ministry of Tourism, 1996). The idea of interviewing tourists at the Wailing Wall itself was rejected for three main reasons. First, tourists on their way from one site to another might not be happy to participate in an interview. Second, some of the tourists would be part of a tour group and as such it would be difficult to interview them. Such tourists could be excluded from the study, but they might prove to be a significant segment. Third, some of the tourists were emotionally involved in the tourist experience or were involved in prayer rituals while at the site. The researchers felt it was unethical to interfere in such experiences with the various interview procedures.

The fieldwork was planned for a period when there would be maximum diversity of tourists in Israel, which meant avoiding specific religious holidays as well as a papal visit which took place in 2000. A pilot survey took place in December 1999 and the main data collection between mid-April and mid-May, 2000. The interviews were carried out at all times of the day and night, and on both weekdays and weekends to achieve maximum diversity.

The research instrument was a structured questionnaire implemented through face-to-face interviews with tourists at Ben-Gurion Airport after they had completed their visit to Israel, and had passed through passport control. The use of face-to-face interviews has particular importance here as at the time of the interview respondents had already been involved in security interviews (part of the airport check-in process) possibly lasting 30 minutes or more.

The interviews were conducted by five interviewers from the Business School at Ben-Gurion University in Israel. The interviewers were selected based on an interview with one of the authors, an academic reference, their knowledge of English, and a recommendation from the administrative manager of their course. The interviewers were not aware of the specific objectives of the research in order to reduce the likelihood that they might lead the interviewees to give certain answers. 
It was suspected that the questions dealing with religious affiliation and strength of religious belief might be considered private by the participants. This could also be true for some of the questions about the site itself. It was also taken into account that during the interviews participants were often sitting next to colleagues, friends or family at the airport a factor that could lead to social pressure reflected in the answers provided. It was decided to use show cards to allow participants to indicate their responses via touching the card, or announcing their answers in the form of numbers rather than words. It was hoped this would elicit the participants' true opinions.

The objective of the sampling strategy chosen (a theoretical sample) was not to achieve a representative sample of all international tourists visiting Israel in general or the Wailing Wall in particular, but to include a diversity of tourists who would be able to provide data relevant for the investigation of the research problem. The reason for confining the population to international tourists was based on the assumption that there is greater diversity among this group than among the local population. The actual population used was individuals who identified themselves as international tourists leaving Israel through BenGurion Airport who were able to speak and understand English and were above 15 years old (as at this age cognitive abilities are considered to be stable: Apter et al., 1998). Every $n$th tourist in the duty-free area was approached (where the value of $n$ was determined by factors such as the number of interviewers and the number of flights departing in a certain period).

It was decided to frame the tourist experience by studying behaviour linked to the time before, during and after the visit. It is suggested that this provides a suitable framework for any future discussion. As far as the period before the visit is concerned, the tourists were asked a series of questions dealing with their motivation to visit the site. Another set of questions dealt with the tourists' visitation patterns to the site and their perception of the visit as a heritage experience. Other questions dealt with their future behaviour. At the end of the interview the tourists were asked a series of questions about their personal characteristics (e.g. age group, gender, the place in which they spend most of their life, present place of residence, income, level of formal education, features of their personal group, marital status).

In this study it was decided to follow the line proposed by some anthropologists that religion is something that cannot easily be defined (Agassi, 1980; Guthrie, 1980). By its very nature religion is multi-dimensional (Fukuyama, 1961; Gorlow \& Schroeder, 1968; King, 1972), and as such, a definition for religion was not introduced for the participants. The participants were asked to indicate which religion they were born into and if they still belonged to the same religion. Religiosity has been measured in different ways in the literature (Benson, 1981; King, 1972). Examples of approaches to its measurement are the number of times someone visits places of prayer, someone's belief in religious concepts, a person's approach towards the events described in holy books, or even donations to religious institutions (Benson, 1981; De Jong et al., 1976; King, 1972). As this study emphasises the tourists' subjective perception rather than an objective concept, respondents were asked to report on their own perception of their strength of religious belief.

The findings presented are based on descriptions of association as well as 
differences between groups based on averages. The associations reported are based on a significance level of 0.05 . As far as differences between more than two groups are concerned, a Tukey test was used with a level of significance of 0.1 . The analysis was conducted via SPSS 10.

\section{Results}

This section begins with a description of the sample. Following this, the relationship between the tourists' visitation patterns and their religious affiliation is presented. A description of the relationship between the tourists' strength of religious belief and the visitation patterns is then given.

\section{Description of the sample}

The entire sample consisted of 398 participants, of whom 304 (77.55\%) had visited the Wailing Wall during their present stay. Of this 304,57.6\% were male and $42.4 \%$ female (the gender distribution for the entire sample was $61.8 \%$ male and $38.2 \%$ female). This unequal ratio of men to women could be due to business travellers, who are more likely to be men than women. The mode age group was 20-29, both among those who visited the Wailing Wall $(26.7 \%)$ and the total sample $(26.5 \%)$. The tourists were provided with 11 religious categories to report on their present religious affiliation: five subgroups of Judaism (Strictly Orthodox, Orthodox, Conservative, Reformed, No Affiliation), three subgroups of Christianity (Protestant, Catholic, Other), Moslem, Other and No Affiliation. Among those who visited the Wailing Wall, 24.7\% (75) were Jewish, 64.8\% were Christians (197) and 8.7\% identified themselves as Muslims, 'Other' and 'No Affiliation' (1.8\% did not answer the question). Following this, participants were asked about the religion they were born into, to avoid missing any situation where a person had changed from one religion to another. Based on the data, $90.13 \%$ of the participants indicated that they still belonged to the religion they were born into while $9.8 \%$ (30 participants) had changed their religion. Of this 30, three Christian participants had moved to 'No Affiliation' and the other 27 respondents had changed their grouping but still belonged to the same main religion.

In the context of this study, there is scope to clarify possible relationships concerning the tourists' strength of religious belief. Respondents were asked to report on their strength of religious belief using a zero to six scale (where 0 represents 'not religious at all' and 6 represents 'extremely religious'). For the purpose of analysis it was decided to classify the tourists into three groups: (1) those who answered 0 and 1 (who will be considered 'not religious'), (2) those who answered 2 to 4 (who will be considered 'moderately religious') and (3) those who answered 5 and 6 (who will be considered 'religious'). Of those who visited the Wailing Wall sample, $19.4 \%$ were not religious, $37.5 \%$ were moderately religious and $42.4 \%$ were religious.

In the context of the questions dealing with the actual visitation patterns to the site, a comparison was made between the Jewish and Christian tourists (the size of the other groups was often not large enough to allow further analysis, although this was subject to the sample size (i.e. the full sample or just those who visited the site), the test used and the number of groups compared). A $t$-test was conducted to reveal any difference in strength of religious belief. The average 
strength of belief of the Jewish (2.24) and the Christian tourists (2.35) was not found to be significantly different.

\section{The relationship between the tourists' visitation patterns and their religious affiliation}

The tourists were asked about their perception of the Wailing Wall as part of their own heritage using a zero to six scale (where 0 indicates 'absolutely not part of my own heritage' and 6 indicates 'absolutely part of my own heritage'). A one-way ANOVA test indicated that there are significant differences $(F=52.536$, $d f=4$, chi-squared $=168.761$, sig. $=0.000$ ) between the tourists based on their religious affiliation. The differences are presented in Table 1.

As can be seen, Jewish participants were different from the other groups. These results are not surprising as it is reasonable to assume that Jews would consider the site to be more linked to their heritage than would other groups. The same pattern of answers was found in the context of the tourists' subjective awareness of the site. A one-way ANOVA test indicated a clear difference among the tourists' subjective awareness of the history of the Wailing Wall ( $F=11.258$, sig. $=0.000$, chi-squared $=11.258, d f=4$, asymp. sig. $=0.000)$. Table 2 describes the actual differences found, and shows that Jewish participants with the highest level of subjective awareness are significantly different from Christians, and those identified as belonging to 'Other' religions. This can be explained by the fact that the Wailing Wall, as part of the Temple, is at the heart of the Jewish faith, and as such Jewish participants felt a sense of familiarity with the history of the site.

The tourists were then presented with possible motives for their visits and were asked to indicate their level of agreement for each in turn (where 0 indicates 'absolutely disagree' and 6 'absolutely agree'). These statements were linked to the Wailing Wall being a heritage site, a place for worship, a 'must see' site, or a place they wanted to learn about. Table 3 identifies the different answers for Jewish and Christian tourists. As can be seen, those reasons that exhibit significant

Table 1 Differences between tourists' perception of the Wailing Wall as part of their own heritage based on their religion

\begin{tabular}{|l|c|l|c|c||}
\hline Religious affiliation & Mean & Religious affiliation & Mean & P value \\
\hline Jewish & 5.76 & Christian & 2.375 & 0.000 \\
\hline Jewish & 5.76 & Moslem & 1.000 & 0.003 \\
\hline Jewish & 5.76 & No Affiliation & 1.428 & 0.000 \\
\hline Jewish & 5.76 & Other & 1.608 & 0.000 \\
\hline
\end{tabular}

Table 2 Differences between the tourists' subjective awareness of the history of the Wailing Wall in relation to their religion

\begin{tabular}{|l|c|l|c|c||}
\hline \hline Religious affiliation & Mean & Religious affiliation & Mean & P value \\
\hline Jewish & 5.226 & Christian & 4.030 & 0.000 \\
\hline Jewish & 5.226 & Other & 3.739 & 0.000 \\
\hline
\end{tabular}


Table 3 Differences between tourists' motivations to visit the site based on their religious affiliation

\begin{tabular}{|c|c|c|c|}
\hline You visited the site: & $\begin{array}{l}\text { Jewish mean } \\
\quad(\mathrm{n}=75)\end{array}$ & $\begin{array}{l}\text { Christian mean } \\
(\mathrm{n}=197)\end{array}$ & P value \\
\hline $\begin{array}{l}\text { because of its religious } \\
\text { characteristics }\end{array}$ & 5.3333 & 4.5228 & 0.000 \\
\hline $\begin{array}{l}\text { because of its historic } \\
\text { background }\end{array}$ & 5.5333 & 5.0558 & 0.005 \\
\hline $\begin{array}{l}\text { because it was on your way to } \\
\text { another site }\end{array}$ & 0.5867 & 1.3249 & 0.003 \\
\hline $\begin{array}{l}\text { because you wanted to have a } \\
\text { day out }\end{array}$ & 0.7200 & 0.6548 & 0.738 \\
\hline because there was no entrance fee & 0.2133 & 0.4264 & 0.150 \\
\hline $\begin{array}{l}\text { because of the physical nature of } \\
\text { the site }\end{array}$ & 2.8533 & 2.5990 & 0.394 \\
\hline $\begin{array}{l}\text { because you wanted to learn } \\
\text { about the site }\end{array}$ & 3.2667 & 4.4010 & 0.000 \\
\hline $\begin{array}{l}\text { because you felt you should visit } \\
\text { the site }\end{array}$ & 5.0267 & 3.8832 & 0.000 \\
\hline $\begin{array}{l}\text { because it is part of your own } \\
\text { heritage }\end{array}$ & 5.4000 & 2.1218 & 0.000 \\
\hline $\begin{array}{l}\text { because you wanted to have } \\
\text { some entertainment }\end{array}$ & 0.9867 & 0.6802 & 0.120 \\
\hline because you wanted to pray there & 4.4267 & 2.2437 & 0.000 \\
\hline $\begin{array}{l}\text { because you wanted to feel } \\
\text { emotionally involved }\end{array}$ & 4.7200 & 2.3503 & 0.000 \\
\hline $\begin{array}{l}\text { because you felt obliged to visit } \\
\text { the site }\end{array}$ & 3.8667 & 1.5787 & 0.000 \\
\hline $\begin{array}{l}\text { because you felt a sense of } \\
\text { belonging to the site }\end{array}$ & 5.1733 & 2.0914 & 0.000 \\
\hline $\begin{array}{l}\text { because you thought it was } \\
\text { important to visit the site }\end{array}$ & 5.3867 & 4.4365 & 0.000 \\
\hline $\begin{array}{l}\text { because it is a world famous site } \\
\text { that you had to see once in your } \\
\text { life }\end{array}$ & 1.4667 & 3.0863 & 0.000 \\
\hline because you wanted to relax & 0.5733 & 0.6294 & 0.757 \\
\hline
\end{tabular}

differences can be classified into two groups. The first group consists of those reasons that are associated with the site being part of the tourist's own heritage, where Jewish participants had higher scores (e.g. 'because you felt a sense of belonging to the site'). The other group consists of reasons linked to the site being an historic tourist attraction (e.g. 'because it is a world famous site'). In this group the Christian participants had a higher average score compared to Jewish participants. No differences were found between statements suggesting that the reason for the visit was fun or entertainment, as all participants rejected these as potential reasons for visiting the site.

The tourists were asked to comment on several statements concerning their perception of the actual visit as a heritage experience (where 0 indicates 'absolutely 
Table 4 Differences between tourists' perceptions of the visit to the Wailing Wall based on their religion

\begin{tabular}{||l|l|c|l|c|c||}
\hline \hline \multirow{2}{*}{$\begin{array}{l}\text { The visit to the site } \\
\text { moved you } \\
\text { emotionally }\end{array}$} & $\begin{array}{l}\text { Religious } \\
\text { affiliation }\end{array}$ & Mean & $\begin{array}{l}\text { Religious } \\
\text { affiliation }\end{array}$ & Mean & P value \\
\cline { 2 - 6 } & Jewish & 5.053 & Christian & 3.533 & 0.000 \\
\cline { 2 - 6 } & Jewish & 5.053 & Moslem & 1.000 & 0.058 \\
\hline $\begin{array}{l}\text { During the visit } \\
\text { you felt that part of } \\
\text { your own heritage } \\
\text { was displayed }\end{array}$ & Jewish & 5.053 & No Affiliation & 2.956 & 0.000 \\
\cline { 2 - 6 } & Jewish & 5.013 & Christian & 2.040 & 0.000 \\
\hline $\begin{array}{l}\text { The visit to the site } \\
\text { made you feel } \\
\text { proud }\end{array}$ & Jewish & 5.013 & No Affiliation & 1.782 & 0.000 \\
\cline { 2 - 6 } & Jewish & 4.413 & Christian & 1.715 & 0.000 \\
\cline { 2 - 6 } & Jewish & 4.413 & Moslem & 0.000 & 0.071 \\
\cline { 2 - 6 } & Jewish & 4.413 & Other & 1.285 & 0.007 \\
\hline
\end{tabular}

disagree' and 6 'absolutely agree'). Again, significant differences were found between the tourists based on their religion. The data presented in Table 4 suggest that the tourists' religion was associated with their perception of the site. Jewish participants perceived the site as being more related to their heritage, and the visit caused them to be more emotionally involved than tourists who belonged to other religious groups.

In the context of the tourists' behaviour at the site, significant differences were found in the frequency of visits to the site, both in the past and during the present visit to Israel. Jewish tourists visited the Wailing Wall more often than other religious groups, both on past trips and during the current visit.

A pattern was also found in the context of the respondents' involvement in tour groups during their visit to the Wailing Wall. Of the Jews visiting the site, only $10.67 \%$ did so in a tour group, while for Christians this figure was $51.3 \%$. A possible explanation may be because Jews who came to visit the Wailing Wall wanted to experience something personal; being a part of a group could be a barrier to such an experience. Another possible explanation is that because Jews had a higher level of subjective awareness of the history of the site, and had visited the site more often in the past, they did not feel the need to be part of a tour group. These explanations may also be relevant to differences in the use of interpretation methods at the site. Of the Jews interviewed, $58.7 \%$ used interpretation methods, while among Christians the figure was $93.4 \%$. Another aspect explored was the tourists' satisfaction from the visit. In this context significant differences were found between Jews and other groups. Jewish participants had a very high level of satisfaction from the visit (5.53) while the level for the other groups varied between 3.5 (for Moslems) and 4.9 (for Christians).

The tourists were asked a series of questions about their intention to visit the site in the future and their intention to recommend such a visit to their friends. These two questions were also asked in the hypothetical situation of there being an entrance fee (entrance to the site is currently free). As can be seen from Table 5, significant differences were found again between the tourists based on their religious affiliation. 
Table 5 Differences between tourists' possible behaviour in the future in relation to their religion

\begin{tabular}{||l|l|c|l|c|c||}
\hline \hline & $\begin{array}{l}\text { Religious } \\
\text { affiliation }\end{array}$ & Mean & $\begin{array}{l}\text { Religious } \\
\text { affiliation }\end{array}$ & Mean & P value \\
\hline $\begin{array}{l}\text { If you visit Israel in the } \\
\text { future you will revisit } \\
\text { the site }\end{array}$ & Jewish & 5.826 & Christian & 4.604 & 0.000 \\
\cline { 2 - 6 } & Jewish & 5.826 & Moslem & 2.000 & 0.039 \\
\cline { 2 - 6 } & Jewish & 5.826 & Other & 3.428 & 0.011 \\
\cline { 2 - 6 } & Jewish & 5.826 & No Affiliation & 3.695 & 0.000 \\
\hline $\begin{array}{l}\text { You would visit the site } \\
\text { even if you had to pay } \\
\text { an entrance fee }\end{array}$ & Jewish & 5.520 & Christian & 4.147 & 0.000 \\
\cline { 2 - 6 } $\begin{array}{l}\text { You would recommend } \\
\text { a visit to the site to your } \\
\text { friends if they visit } \\
\text { Israel }\end{array}$ & Jewish & 5.520 & Other & 2.142 & 0.000 \\
\cline { 2 - 6 } & Jewish & 5.853 & Christian & 5.350 & 0.009 \\
\cline { 2 - 6 } & Moslem & 3.000 & Christian & 5.350 & 0.028 \\
\cline { 2 - 6 } & Moslem & 3.000 & Other & 5.285 & 0.088 \\
\hline Moslem & 3.000 & No Affiliation & 5.434 & 0.029 \\
\hline $\begin{array}{l}\text { You would recommend } \\
\text { a visit to the site to your } \\
\text { friends even if they had } \\
\text { to pay an entrance fee }\end{array}$ & Jewish & 5.600 & Christian & 4.989 & 0.026 \\
\hline \hline
\end{tabular}

Based on the data Table 5, it appears that the tourists' potential behaviour in the future is associated with their religion. Moslem tourists are less willing to recommend a visit to the Wailing Wall to their friends if they visit Israel in the future. Jewish participants generally speaking have a higher intention to revisit the site, even if an entrance fee were charged, plus a higher intention to recommend a visit to their friends.

Based on the differences found between Jewish, Christian and Muslim tourists, the principal conclusion of this section is that the tourists' religion was linked to their behaviour before, during and after the visit. Differences were also found in the tourists' perception of the site, as well as the visit itself. This may suggest that, although it is the same site, tourists were exposed to different experiences during their visit, linked to their perception of the site in relation to their own heritage.

\section{The relationship between the tourists' strength of religious belief and their visitation patterns}

Clear differences were found between the tourists based on their strength of religious belief and their motivations to visit the site. Table 6 shows the various motivations for which significant differences were found. The tourists' responses to the questions dealing with their perception of the visit also indicated clear differences among the groups. As can be seen from Table 7; those who have a strong religious belief perceived the visit as more linked to their own heritage and contributing to their education than others.

In terms of actual visitation patterns to the site, differences were found in the number of visits to the site prior to this visit. Those who identified themselves as 
Table 6 Differences between tourists' motivations to visit the Wailing Wall based on their strength of religious belief

\begin{tabular}{|l|c|c|c|c|c||}
\hline $\begin{array}{l}\text { You visited the } \\
\text { site: }\end{array}$ & $\begin{array}{c}\text { Not } \\
\text { religious } \\
\text { Group I } \\
\text { (n= 36) }\end{array}$ & $\begin{array}{c}\text { Moderately } \\
\text { religious } \\
\text { Group II } \\
\text { (n= 111) }\end{array}$ & $\begin{array}{c}\text { Religious } \\
\text { Group III } \\
\text { (n = 123) }\end{array}$ & P value & $\begin{array}{c}\text { Identified } \\
\text { differences } \\
\text { between } \\
\text { groups }\end{array}$ \\
\hline $\begin{array}{l}\text { because of its } \\
\text { religious } \\
\text { characteristics }\end{array}$ & 4.02 & 4.33 & 5.31 & 0.05 & $\begin{array}{c}\text { I, III } \\
\text { II, III }\end{array}$ \\
\hline $\begin{array}{l}\text { because you } \\
\text { wanted to have a } \\
\text { day out }\end{array}$ & 1.19 & 0.72 & 0.47 & 0.05 & I, III \\
\hline $\begin{array}{l}\text { because you } \\
\text { wanted to have } \\
\begin{array}{l}\text { some } \\
\text { entertainment }\end{array}\end{array}$ & 1.08 & 0.91 & 0.54 & 0.1 & I, II \\
\hline $\begin{array}{l}\text { because you } \\
\text { wanted to pray } \\
\text { there }\end{array}$ & 1.27 & 2.46 & 3.64 & 0.05 & II, III \\
\hline $\begin{array}{l}\text { because you } \\
\text { wanted to feel } \\
\text { emotionally } \\
\text { involved }\end{array}$ & 2.47 & 2.82 & 3.31 & 0.1 & \\
\hline $\begin{array}{l}\text { because you felt a } \\
\text { sense of } \\
\text { belonging to the } \\
\text { site }\end{array}$ & 2.33 & 2.77 & 3.26 & 0.1 & \\
\hline \hline
\end{tabular}

Table 7 Differences between tourists' perceptions of the visit based on their strength of religious belief

\begin{tabular}{|l|c|c|c|c|c||}
\hline & $\begin{array}{c}\text { Not } \\
\text { religious } \\
\text { Group I } \\
\text { (n = 36) }\end{array}$ & $\begin{array}{c}\text { Moderately } \\
\text { religious } \\
\text { Group II } \\
\text { (n = 111) }\end{array}$ & $\begin{array}{c}\text { Religious } \\
\text { Group III } \\
\text { (n= 123) }\end{array}$ & P value & $\begin{array}{c}\text { Identified } \\
\text { differences } \\
\text { between } \\
\text { groups }\end{array}$ \\
\hline $\begin{array}{l}\text { The visit to the } \\
\text { site contributed } \\
\text { to your education }\end{array}$ & 3.38 & 4.12 & 4.28 & 0.054 & I, III \\
\hline $\begin{array}{l}\text { The visit to the } \\
\text { site moved you } \\
\text { emotionally }\end{array}$ & 3.36 & 3.90 & 4.16 & 0.092 & I, III \\
\hline $\begin{array}{l}\text { During the visit } \\
\text { you felt that part } \\
\text { of your heritage } \\
\text { was displayed }\end{array}$ & 1.94 & 2.80 & 3.17 & 0.022 & I, III \\
\hline $\begin{array}{l}\text { The visit to the } \\
\text { site made you } \\
\text { feel proud }\end{array}$ & 1.63 & 2.37 & 2.73 & 0.051 & I, III \\
\hline
\end{tabular}


religious had visited the site on average 21 times, those who identified themselves as moderately religious had visited the site 7.6 times and those who were not religious had visited the site only 4.3 times. One reason for this high number of visits is because some participants visit the site more than once per visit to Israel, and some had visited Israel on numerous occasions.

A pattern was also found in the context of the respondents' involvement in tour groups. Of the religious group $48.7 \%$ were part of a tour group, while among those who were not religious, only $19.4 \%$ were. Intersecting this information with the tourists' religion reveals that religious Christian tourists were commonly part of a tour group. More of those who consider themselves not to be religious $(47.2 \%)$ used a tourist guidebook compared to those who consider themselves religious, of whom only $23.5 \%$ used one. A possible reason for this could be that the more tourists felt religious the more they felt familiar with the history of the site $(F=3.779, d f=2$, sig. $=0.024)$. No differences were found among the tourists in terms of their satisfaction from the visit, or the number of times they visited the site on this trip to Israel.

In relation to the tourists' potential behaviour in the future, significant differences were found in relation to intention to visit the site in the future if an entrance fee were to be charged $(p<0.078)$. However, the actual differences among the groups were not significant.

\section{Integration of the tourists' religion and their strength of religious belief}

From the data provided above, it appears that the tourists' strength of religious belief and their religious affiliation are linked to various aspects of the visitation patterns. As this site is one where religion is central to its significance, differences in the visitation patterns can be explained relatively easily, and they suggest that both religious affiliation and religiosity are linked to tourists' visitation patterns. The results show that Jewish tourists are different from the other groups in relation to their motivation to visit the site, their perception of the visit itself, the actual visit to the site, and their likely behaviour in the future. It is argued also that those who identify themselves as tourists with a high level of religious belief are different from the other groups. The numbers of actual differences related to religion, as well as the magnitude of these differences, were higher when the tourists' strength of religious belief was explored.

These differences support the theoretical framework which suggests that, in the context of heritage sites, the tourists' visitation patterns and their experience of a site are influenced by several factors and should be explored based on the link between the heritage presented and the tourists visiting the site (Poria, 2001; Poria et al., 2001a, 2001b, 2003a). It is argued that a site's heritage represents different things with different meanings to different tourists, and those meanings are at the core of the understanding of tourist behaviour in that setting. As the site in question here relates to the monotheistic religions and carries symbolic meaning for those who follow Judaism and Christianity, the tourists' strength of religious belief could be expected to influence their visitation patterns. We also need to bear in mind that the site is associated with Jewish people and Zionism (as a symbol of independence for the Jewish State), following two millennia of being controlled by others. The site holds a different meaning for Zionist Jews 
Table 8 The division of tourists based on their main religious belief and their distribution into 'religious' 'moderately religious' and 'strongly religious'

\begin{tabular}{||l|l|c|c|l||}
\hline \begin{tabular}{|} 
Tourists' strength \\
of religious belief
\end{tabular} & $\begin{array}{c}\text { The tourists' main } \\
\text { present religion: } \\
\text { Jewish }\end{array}$ & $\begin{array}{c}\text { The tourists' main } \\
\text { present religion: } \\
\text { Christian }\end{array}$ & Total \\
\hline \multirow{2}{*}{ Not religious } & Count & 13 & 23 & 36 \\
\cline { 2 - 5 } & Expected count & 10.0 & 26.0 & 36.0 \\
\hline \multirow{2}{*}{$\begin{array}{l}\text { Moderately } \\
\text { religious }\end{array}$} & Count & 31 & 80 & 111 \\
\cline { 2 - 5 } Religious & Expected count & 30.8 & 80.2 & 111.0 \\
\cline { 2 - 5 } & Count & 31 & 92 & 123 \\
\cline { 2 - 5 } & Expected count & 34.2 & 88.8 & 123.0 \\
\cline { 2 - 5 } & Count & 75 & 195 & 270 \\
\hline
\end{tabular}

Table 9 The correlation between the tourists' perception of the site in relation to their own heritage and the tourists' strength of religious belief

\begin{tabular}{|c|c|c|}
\hline Tourists' main religion & Level of association & Pvalue \\
\hline Jewish (all the sample) & 0.261 & 0.004 \\
\hline $\begin{array}{l}\text { Jewish (those who have visited the site } \\
\text { on their present visit to Israel only) }\end{array}$ & 0.319 & 0.005 \\
\hline Christians (all the sample) & 0.087 & 0.206 \\
\hline $\begin{array}{l}\text { Christians (those who have visited the } \\
\text { site on their present visit to Israel only) }\end{array}$ & 0.071 & 0.327 \\
\hline All the sample & 0.099 & 0.054 \\
\hline $\begin{array}{l}\text { Those who have visited the site on their } \\
\text { present visit to Israel }\end{array}$ & 0.092 & 0.111 \\
\hline
\end{tabular}

than for others. It is suggested, based on the results of this study, that these two factors are central to understanding participants' behaviour, as they explain the link between the site and the heritage presented.

To understand better the relationship between tourists' religion and their strength of religious belief in the context of the Wailing Wall, in this section a comparison is made between Jewish and Christian tourists (Table 8). This comparison will be based on their strength of religious belief, to illustrate that both the tourists' religion and their strength of religious belief need to be taken into account to explain their behaviour. First, a chi-squared test comparing the tourists' strength of religious belief based on their religious affiliation was carried out. This test indicated that there were no significant differences between the Christian and Jewish tourists in their internal distribution to 'not religious' 'moderately religious' and 'religious' (Pearson chi-squared $=1.645$, $d f=2$, asymp. sig. (two-sided) $=0.437)$.

The differences presented in Table 9 exemplify the link with the tourists' perception of the site in relation to their own heritage as well as the visitation patterns at the site. As it is argued that the tourists' perception of the site in relation 
Table 10 Division of tourists based on their main religious belief, their strength of religious belief and specific aspects of their visit

\begin{tabular}{|c|c|c|c|c|c|c|c|}
\hline & \multirow{2}{*}{$\begin{array}{l}\text { Tourists' } \\
\text { strength of } \\
\text { religious } \\
\text { belief }\end{array}$} & \multicolumn{3}{|c|}{ Jewish } & \multicolumn{3}{|c|}{ Christian } \\
\hline & & $\mathbf{N}$ & Mean & $\begin{array}{l}\text { Standard } \\
\text { deviation }\end{array}$ & $\mathbf{N}$ & Mean & $\begin{array}{l}\text { Standard } \\
\text { deviation }\end{array}$ \\
\hline \multirow{4}{*}{$\begin{array}{l}\text { Site has } \\
\text { symbolic } \\
\text { meaning for } \\
\text { you }\end{array}$} & 1 & 13 & 4.7692 & 1.3634 & 23 & 1.8261 & 2.2493 \\
\hline & 2 & 31 & 4.8710 & 1.2581 & 80 & 3.0375 & 2.1432 \\
\hline & 3 & 31 & 5.4194 & 1.3360 & 92 & 3.6413 & 2.2365 \\
\hline & Total & 75 & 5.0800 & 1.3230 & 195 & 3.1795 & 2.2621 \\
\hline \multirow{4}{*}{$\begin{array}{l}\text { Site generates } \\
\text { a sense of } \\
\text { belonging for } \\
\text { you }\end{array}$} & 1 & 13 & 4.1538 & 1.7723 & 23 & 0.7391 & 1.0962 \\
\hline & 2 & 31 & 4.6129 & 1.3827 & 80 & 1.9625 & 1.9056 \\
\hline & 3 & 31 & 5.8710 & 0.4275 & 92 & 2.1957 & 2.3592 \\
\hline & Total & 75 & 5.0533 & 1.3645 & 195 & 1.9282 & 2.1042 \\
\hline \multirow{4}{*}{$\begin{array}{l}\text { Future: you } \\
\text { intend to } \\
\text { revisit the site }\end{array}$} & 1 & 13 & 5.6923 & 0.7511 & 23 & 4.3043 & 1.5502 \\
\hline & 2 & 31 & 5.7097 & 0.6426 & 80 & 4.3750 & 1.7238 \\
\hline & 3 & 31 & 6.0000 & 0.0000 & 92 & 4.8696 & 1.8529 \\
\hline & Total & 75 & 5.8267 & 0.5295 & 195 & 4.6000 & 1.7773 \\
\hline \multirow{4}{*}{$\begin{array}{l}\text { Future: you } \\
\text { intend to } \\
\text { recommend } \\
\text { the site }\end{array}$} & 1 & 13 & 5.7692 & 0.8321 & 23 & 5.3913 & 0.7223 \\
\hline & 2 & 31 & 5.7419 & 0.6308 & 80 & 5.3625 & 0.9968 \\
\hline & 3 & 31 & 6.0000 & 0.0000 & 92 & 5.3261 & 1.2676 \\
\hline & Total & 75 & 5.8533 & 0.5376 & 195 & 5.3487 & 1.1036 \\
\hline
\end{tabular}

$1=$ those who answered 0 and 1 (considered as 'not religious')

2 = those who answered 2 to 4 (considered as 'moderately religious'

$3=$ those who answered 5 and 6 (considered as 'religious')

to their own heritage is at the core of heritage tourism (Poria et al., 2001a, 2001b, 2003a), the link between this and the tourists' strength of religious belief is presented first. As Table 9 demonstrates, the tourists' perception of the site in relation to their own heritage is significantly linked to the strength of their religious belief among Jewish participants but not among Christian participants. This difference may explain the differences presented in the following tables which deal with the tourists' visitation patterns.

Table 10 concerns the perception of the site as well as the tourists' stated future behaviour. Again the same pattern as described earlier is demonstrated here; when the tourists' strength of religious belief is linked to their responses, the Jewish participants show much higher scores than the Christians. The table demonstrates that the actual link between the tourists' strength of religious belief and other factors is different between the Jewish and Christian tourists. To support this thought the linear relationship between the tourists' strength of religious belief and their religious affiliation was explored. Table 11 contains some more examples in which significant differences were found between the correlation coefficients of the two groups via the use of Fisher's $Z$ statistic and comparison to the critical $Z$ values. The data presented suggest that a tourist's strength of religious belief is linked to the visitation patterns, and that it has more influence among Jewish participants than among Christians. 
Table 11 Division of tourists based on their main religious belief, their strength of religious belief and specific aspects of their visit

\begin{tabular}{|c|c|c|c|c|c|c|c|c|}
\hline & \multicolumn{3}{|c|}{ Jewish $(\mathrm{n}=75)$} & \multicolumn{3}{|c|}{ Christian $(\mathrm{n}=197)$} & \multicolumn{2}{|c|}{$\begin{array}{c}\text { Fisher's Z } \\
\text { statistic }\end{array}$} \\
\hline & Mean & $\begin{array}{l}\text { Std } \\
\text { dev. }\end{array}$ & $\begin{array}{c}\text { Pearson } \\
\text { correlation }\end{array}$ & Mean & $\begin{array}{l}\text { Std } \\
\text { dev. }\end{array}$ & $\begin{array}{c}\text { Pearson } \\
\text { correlation }\end{array}$ & \begin{tabular}{|c|}
$\mathrm{Z}$ \\
score \\
\end{tabular} & \begin{tabular}{|c}
$\mathbf{P}$ \\
value
\end{tabular} \\
\hline Satisfaction & 5.53 & 0.72 & 0.419 & 4.90 & 1.18 & 0.030 & 3.014 & 0.001 \\
\hline \multicolumn{9}{|c|}{ Reasons for visiting the site } \\
\hline $\begin{array}{l}\text { Because you } \\
\text { wanted to } \\
\text { pray there }\end{array}$ & 4.42 & 2.21 & 0.611 & 2.24 & 2.41 & 0.297 & 2.927 & 0.001 \\
\hline $\begin{array}{l}\text { Because you } \\
\text { felt obliged to } \\
\text { visit the site }\end{array}$ & 3.86 & 2.30 & 0.283 & 1.57 & 2.08 & 0.017 & 1.978 & 0.005 \\
\hline $\begin{array}{l}\text { Because it is a } \\
\text { world famous } \\
\text { site }\end{array}$ & 1.46 & 2.18 & -0.325 & 3.08 & 2.34 & 0.069 & -2.01 & 0.001 \\
\hline \multicolumn{9}{|c|}{ Questions about the visit and the site } \\
\hline $\begin{array}{l}\text { You felt that } \\
\text { part of your } \\
\text { heritage was } \\
\text { displayed }\end{array}$ & 5.01 & 1.52 & 0.480 & 2.04 & 2.13 & 0.181 & 2.456 & 0.001 \\
\hline $\begin{array}{l}\text { You know } \\
\text { more about it } \\
\text { compared to } \\
\text { other sites in } \\
\text { Israel }\end{array}$ & 4.77 & 1.41 & 0.248 & 3.10 & 1.68 & -0.063 & 2.289 & 0.001 \\
\hline $\begin{array}{l}\text { The site } \\
\text { represents } \\
\text { something } \\
\text { which is } \\
\text { relevant to } \\
\text { your present } \\
\text { existence }\end{array}$ & 4.81 & 1.70 & 0.447 & 2.08 & 2.08 & 0.201 & 2.0 & 0.001 \\
\hline $\begin{array}{l}\text { The site } \\
\text { generates a } \\
\text { sense of } \\
\text { belonging for } \\
\text { you }\end{array}$ & 5.05 & 1.36 & 0.501 & 1.93 & 2.10 & 0.186 & 2.62 & 0.001 \\
\hline $\begin{array}{l}\text { Satisfaction } \\
\text { from the visit }\end{array}$ & 5.53 & 0.72 & 0.419 & 4.90 & 1.18 & 0.030 & 3.014 & 0.001 \\
\hline
\end{tabular}

\section{Conclusions}

\section{Summary}

The results of the study indicate that both the concepts explored were linked to the tourists' visitation patterns and their experience of the site examined. Due to the nature of the sample, a comparison was made between Jewish and Christian tourists. The results indicated clear differences between Jewish and Christian participants. Jewish tourists were motivated to visit the site more by their 
desire for an emotional experience. They perceived the visit as a 'heritage experience', and their intention to visit the site in the future is much higher. Based on existing lines of discussion in heritage tourism literature, it is suggested here that the Jewish participants' links with the site are substantially different from those of the other groups involved in this study.

The same pattern of results was found in relation to the tourists' strength of religious belief. Clear differences were found between those tourists who considered themselves to have a high strength of religious belief and those with a low strength of religious belief. Those participants with a high strength of religious belief perceived the site to be more linked to their own heritage, they were more emotionally involved, and expressed a stronger intention to visit the site again in the future. The fact that the results were linked to the tourists' visitation patterns before, during and after the visit indicate that tourists' strength of religious belief should be taken into account also when looking at tourists' overall experience of the site.

It is interesting to note that more differences, of greater magnitude, were found between tourists based on their religious affiliation than on their strength of religious belief. This means, for example, that even the Christians with the highest strength of religious belief were different from the non-religious Jews in relation to visitation patterns linked to the heritage presented at the site. The non-religious Jewish visitors regarded the site as more linked to their heritage than religious Christians, and they also illustrated behaviours which were associated with their perception of the site as part of their own heritage. The actual influence of strength of religious belief among the Jewish participants and the Christians was also different. Among Jews there were more relationships between the tourists' experience of the site and their strength of religious belief than among the Christians, possibly because the Wailing Wall is considered the holiest religious site for Jewish people. Christian believers do not see it as a special holy site in the same way, despite its strong links with Christ.

Although the tourists' religion and their religious beliefs were linked to visitation patterns in this instance, it is not suggested that these parameters will be always linked to or could be used to differentiate between visitation patterns in other tourist settings or even in settings in which heritage is presented. It is argued that the relationships explored here are influenced by the attributes of the site itself. The factors shown to influence the tourists' visitation patterns here may only be relevant if they affect the tourists' perception of the site or are linked to it in an indirect way.

On a more general level, it is argued here that the tourists' religion and their strength of religious belief are linked to the meaning they give the site and this is what influences their visitation patterns. It is concluded that the tourists' experience of the site is not due to the fact that they are Jewish or Christian or because of their strength of religious belief per se. It is suggested that these are simply indicators that may help to understand the meaning a site has for an individual and how that meaning has been 'attached' to the site. It is argued that it is the culture in which participants live that constructs the meaning associated with the site, and this lies at the core of the tourists' experience. It may be that at other sites the tourists' religion will not influence visitation patterns, while other factors might. 


\section{Limitations and future research}

One of the limitations of this study is that only one site was explored. To understand better the relationship between tourists' religion and religiosity it is necessary to explore visitation patterns in further religious, as well as nonreligious, settings. This study concentrates on a site mentioned in the Bible. It may be appropriate to look at sites that are not linked to a belief in God, but associated with some other ideological framework or even new modern 'secular religions' such as football (King, 2002). For example, Manchester United fans carry a sign saying that the club is their religion, and looking at visitors to their headquarters at Old Trafford, Manchester, (the equivalent of a shrine) may unearth more information relevant for our understanding of this social phenomenon. Many football clubs now have a museum at their stadium converting a sporting site into at least partly a heritage site. Research in such museums may suggest that football is just 'sport' for some but for others, it is a part of their own heritage.

The site investigated in this study is linked to the monotheistic religions, and most of the tourists who participated in the study belonged to such religions (Christianity, Judaism and Islam). Further research could look at other religions to see if the same patterns described here exist in other settings. Research concerning spaces that different religions approach in different ways may highlight the link between the heritage presented and tourists' experience of a place. For example, research about visitation patterns to the Blue Mosque (also known as the Santa Sofia or Aya Sofia church) in Istanbul, which was a church in the past, could provide interesting results. Such research could throw more light on the relationships explored here, and would contribute to our theoretical understanding of tourism in heritage spaces in general and for religious sites in particular.

\section{Management implications}

The results of this study indicate that the tourists' visitation patterns are linked to the tourists' religion and their strength of religious belief. On a more theoretical level, participants may be differentiated based on the meaning they attach to the site, and their perception of that site in relation to their own heritage. This may provide information relevant for the operational and strategic management of tourist sites. For example, those who market a religious site may find it appropriate to market the site in different ways to different people, according to their religious affiliation, as they will be motivated to visit the site for different reasons. The fact that tourists could be differentiated based on their strength of religious belief also may influence the way the site is marketed. The results indicate differences in the use of interpretation methods. It may be worthwhile for those who manage and study such sites to determine whether the link between tourists and the heritage presented is useful for understanding the tourists' demand for interpretation methods.

As suggested before, it is argued that other factors can explain tourists' behaviour and their experience of a site in the context of other heritage attractions. To manage such sites better, it is suggested that those who manage heritage attractions need to explore those core factors that affect tourists' perception of a site in relation to their own heritage. 


\section{Theoretical implications}

The results of this study cast some doubts on the emerging body of literature suggesting that heritage tourism, as approached in the tourism literature today, is actually 'tourism in heritage places' rather than 'heritage tourism' (Poria, 2001; Poria et al., 2001a, 2001b, 2003a, 2003b). The results identified here showed that people at the site behaved in different ways, based on their perception of the site in relation to their own heritage. The differences were clear and were linked to visitation patterns before, during and after the visit, and were associated with the tourists' personal characteristics (e.g. tourists' religion and the tourists' strength of religious belief) linked to the site. Those differences should raise some fundamental questions about the nature of heritage tourism as commonly discussed in the literature.

Urry $(1990,1999)$ suggests that there are three dichotomous attributes into which tourist heritage sites can be classified: 'whether they are an object of the romantic or collective tourists' gaze; whether they are historical or modern; and whether they are authentic or inauthentic' (Urry, 1990: 104, 1999: 208). The present researchers suggest that although these attributes may be helpful for our understanding of heritage and the way it impacts tourists, they are not at the core of the phenomenon and may 'hide' the real heritage presented and consumed. At the heart of understanding the tourist (as well as other visitors) lies the 'heritage connection' the tourists' perception of the site in relation to their own heritage which in this study was linked to the individual's religion and strength of religious belief. It is suggested that the characteristics suggested by Urry may be linked to this, but if a researcher wants to understand the heritage experience he or she should look first at the tourists' perception of the site in relation to their own heritage, rather than dealing with site characteristics only. The results of this study also suggest that, in contrast to the attributes suggested by Urry (1990, 1999), the 'perception' attribute is not dichotomous but varies over a continuum. Something could be seen as 'absolutely part of your heritage' or 'absolutely not part of your heritage', but may also be viewed as, for example, 'in contrast to my own heritage', or at any point between those perceptions.

This 'connection' between the tourists and the heritage presented has already been linked to the heritage supplier and the heritage mediator in heritage sites (Ooi, 2002). It was also used to illustrate the place of history in today's nations (Hewison, 1999). However, surprisingly, it has hardly ever been concerned in relation to the actual tourists visiting heritage settings. The final conclusion of this paper is that our understanding of the 'heritage experience' should emphasise the personal subjective link between the site and the individual, rather than look at certain objective dichotomous classifications. As Hewison (1999:159) has said, 'What matters is not the past, but our relationship with it'.

\section{Correspondence}

Any correspondence should be directed to Dr Yaniv Poria, Department of Hotel and Tourism Management, School of Management, Ben-Gurion University of the Negev, Beer-Sheva 84105, P.O.B. 653, Israel (Y.Poria@Bgumail.ac.il). 


\section{References}

Agassi, J. (1980) Comments: A cognitive theory of religion. Current Anthropology 21 (2), 194.

Alavi, J. and Yasin, M.M. (2000) A systematic approach to tourism policy. Journal of Business Research 48, 147-56.

Aner, Z., Ben-Dov, M. and Naor, M. (1981) The Western Wall (in Hebrew). Publishing House, Ministry of Defence of Israel.

Apter, A., Hatab, J., Tyano, S. and Weizinan, A. (1998) Child and Adolescent Psychology (in Hebrew). Tel-Aviv: Dyonon Publishing.

Bailey, J.M. and Sood, J. (1993) The effects of religious affiliation on consumer behavior: A preliminary investigation. Journal of Managerial Issues 5 (3), 328-52.

Benson, J.M. (1981) The polls: A rebirth of religion? Public Opinion Quarterly 45, 576-85.

Brown, P. (1996) Catskill culture: The rise and fall of Jewish resort areas seen through personal narrative and ethnography. Journal of Contemporary Ethnography 25 (1), 83-119.

Brunet, S., Bauer, J., De Lacy, T. and Tshering, K. (2001) Tourism development in Bhutan: Tensions between tradition and modernity. Journal of Sustainable Tourism 9 (3), 243-56.

Cohen, E. (1992a) Pilgrimage and tourism: Convergence and divergence. In A. Morinis (ed.) Sacred Journeys (pp. 47-61). Westport, CT: Greenwood Press.

Cohen, E. (1992b) Pilgrimage centers: Concentric and eccentric. Annals of Tourism Research $19(1), 33-50$.

Cohen, E. (1998) Tourism and religion: A comparative perspective. Pacific Tourism Review 2, 1-10.

Constable, G. (1976) Opposition to pilgrimage in the Middle Ages. Studia Gratiana 19 (1), 123-46.

De Jong, G.F., Faulkner, J.E. and Warland, R.H. (1976) Dimensions of religiosity reconsidered: Evidence from a cross-cultural study. Social Forces 54, 866-89.

Delener, N. (1990) The effects of religious factors on perceived risk in durable goods purchase decisions. Journal of Consumer Marketing 7 (3), 27-38.

Din, K.H. (1989) Islam and tourism: Patterns, issues and options. Annals of Tourism Research 16, 542-63.

Eber, S. and O'Sullivan, K. (1989) Israel and the Occupied Territories. London: Harper-Columbus.

Elboim-Dror, R. (1994) Gender in utopianism: The Zionist case. History Workshop Journal 37, 99-116.

Favreau-Lilie, M.L. (1995) The German empire and Palestine: German pilgrimages to Jerusalem between the 12th and 16th Century. Journal of Medieval History 21, 321-41.

Fleischer, A. (2000) The tourist behind the pilgrim in the Holy Land. International Journal of Hospitality Management 19, 311-26.

Fleischer, A. and Pizam, A. (2002) Tourism constraints among Israeli seniors. Annals of Tourism Research 29 (1), 106-23.

Fukuyama, Y. (1961) The major dimensions of church membership. Review of Religious Research 2, 154-61.

Gorlow, L. and Schroeder, H.E. (1968) Motives for participating in the religious experience. Journal of The Scientific Study of Religion 7, 241-51.

Grigg, D. (1995) The pattern of world protein consumption. Geoforum 26 (1), 1-17.

Guthrie, S. (1980) A cognitive theory of religion. Current Anthropology 21 (2), 181-203.

Henderson, J.C. (2002) Built heritage and colonial cities. Annals of Tourism Research 29 (1), 254-7.

Hewison, R. (1999) The climate of decline. In D. Boswell and J. Evans (eds) Presenting the Nation: Histories, Heritage and Museums (pp. 151-62). London: Routledge.

Hirshman, E.C. (1981) American Jewish ethnicity: Its relationship to some selected aspects of consumer behavior. Journal of Marketing 45, 102-10.

Hitrec, T. (1990) Religious tourism: Development - characteristics - perspectives. Acta Turistica 2 (1), 9-49.

Hood, R.W. and Morris, R.J. (1985) Boundary maintenance, social-political views, and 
presidential preference among high and low fundamentalists. Review of Religious Research 27 (2), 134-45.

Howe, A.C. (2001) Queer pilgrimage: The San Francisco homeland and identity tourism. Cultural Anthropology 16 (1), 35-61.

Israel Ministry of Tourism (1996) Tourist survey. Jerusalem: Israel Ministry of Tourism.

Israel Ministry of Tourism (1997) Tourism to Israel 1996: Statistical report. Jerusalem: Israel Ministry of Tourism.

Israel Ministry of Tourism (1998) Tourism to Israel 1997: Statistical report. Jerusalem: Israel Ministry of Tourism.

Israeli, A. and Mehrez, A. (2000) From illegal gambling to legal gaming: Casinos in Israel. Tourism Management 21 (3), 281-91.

Jackson, R.H. and Hudman, L. (1995) Pilgrimage tourism and English cathedrals: The role of religion in travel. Tourists Review 50 (4), 40-48.

Joseph, C.A. and Kavoori, A.P. (2001) Mediated resistance: Tourism and the host community. Annals of Tourism Research 28 (4), 998-1009.

King, A. (2002) Violent pasts: Collective memory and football hooliganism. Sociological Review 49 (4), 568-85.

King, M. (1972)Measuring the religious variable: Nine proposed dimensions. Journal of the Scientific Study of Religion 6, 173-90.

Knight, J. (1996) Completing hospitalities in Japanese rural tourism. Annals of Tourism Research 23 (1), 165-80.

Krausz, E. (1972) Religion as a key variable. In E. Gittus (ed.) Key Variables in Social Research (pp. 1-33). London: Heinmann Educational.

Lehman, E.C. and Shriver, D.W. (1968) Academic discipline as predictive of faculty religiosity. Social Forces 47, 171-82.

Levin, S. (1979) Understanding religious behavior. Journal of Religion and Health 18 (1), 8-20.

Lupfer, M.B., Brock, K.F. and DePaola, S.J. (1992) The use of secular and religious attributions to explain everyday behavior. Journal of the Scientific Study of Religion31 (4), 486-503.

Lupfer, M. and Wald, K. (1985) An exploration of adults' religious orientations and their philosophies of human nature. Journal of the Scientific Study of Religion 24 (3), 293-304.

Maariv (2002) The target of El-Qaida in Israel: Train stations or the Wailing Wall. On WWW at http: / / maariv.co.il/cache/ART236638. Accessed 17.1.2.

MacCannell, D. (1973) Staged authenticity: Arrangements of social space in tourist settings. American Sociological Review 79, 589-603.

Mansfeld, Y. (1995) The 'value stretch' model and its implementation in detecting tourists' class differentiated destination choice. Journal of Travel and Tourism Marketing 4 (3), 71-92.

Mattila, A.S., Apostolopoulos, Y., Sonmez, S., Yu, L. and Sasidharan, V. (2001) The impact of gender and religion on college students' spring break behavior. Journal of Travel Research 40 (2), 193-200.

McClain, E.W. (1979) Religious orientation the key to psychodynamic differences between feminists and nonfeminists. Journal of the Scientific Study of Religion 18, 40-45.

McDaniel, S.W. and Burnett, J.J. (1990) Consumer religiosity and retail store evaluation criteria. Journal of the Academy of Marketing Science 18 (2), 101-12.

Murray, M. and Graham, B. (1997) Exploring the dialectics of route-based tourism: The Camino de Santiago. Tourism Management 18 (8), 513-24.

Nuryanti, W. (1996) Heritage and postmodern tourism. Annals of Tourism Research 23 (2), 249-60.

Ooi, C.S. (2002) Tourist historical products: Packaged pasts of Denmark and Singapore. Scandinavian Journal of Hospitality and Tourism 1 (2), 113-32.

Poria, Y. (2001) Challenging the present approach to heritage tourism. Tourism Review 56 $(1 / 2), 51-3$.

Poria, Y., Butler, R. and Airey, D. (2001a) Clarifying heritage tourism. Annals of Tourism Research 28 (4), 1047-9.

Poria, Y., Butler, R. and Airey, D. (2001b) Tourism sub-groups: Do they exist? Case study: 
Distinguishing heritage tourism from tourism in heritage places. Tourism Today 1 , $14-22$

Poria, Y., Butler, R. and Airey, D. (2003a) The core of heritage tourism. Annals of Tourism Research 30 (1), 238-54.

Poria, Y., Butler, R. and Airey, D. (2003b) Revisiting Mieczkowski's conceptualisation of tourism. Tourism Geographies 5 (1), 26-38.

Poulson, R.L., Eppler, M.A., Satterwhite, T.N., Wuensch, K.L. and Bass, L.A. (1998) Alcohol consumption, strength of religious belief, and risky sexual behaviour in college students. Journal of American College Health 46 (5), 227-32.

Ragin, C.C. (1994) Constructing Social Research. Thousand Oaks: Pine Forge Press.

Rinschede, G. (1992) Forms of religious tourism. Annals of Tourism Research 19 (1),51-67.

Rokeach, M. (1969) Value systems in religion. Review of Religious Research 11, 2-23.

Russo, A.P. (2002) The 'vicious circle' of tourism development in heritage cities. Annals of Tourism Research 29 (1), 165-82.

Schiller, E. (1992) Guide to Christian Historical Sites and Holy Places in Israel. Jerusalem: Ariel.

Shackley, M. (1999) Tourism development and environmental protection in southern Sinai. Tourism Management 20, 543-8.

Shackley, M. (2001) Managing Sacred Sites: Service Provision and Visitor Experience. New York: Continuum.

Shackley, M. (2002) Potential futures for Robben Island. International Journal of Heritage Studies 7 (4), 355-65.

Shoval, N. and Cohen-Hattab, K. (2001) Urban hotel development patterns in the face of political shifts. Annals of Tourism Research 28 (4), 908-25.

Sigaux (1966) History of Tourism. London: Leisure Art.

Silberman, N.H. (2001) If I forget thee, O Jerusalem: Archaeology, religious commemoration and nationalism in a disputed city, 1801-2001. Nations and Nationalism 7 (4), 487-504.

Smith, V.L. (1992)Introduction: The quest in guest. Annals of Tourism Research19 (1),1-17.

Sood, J. and Nasu, Y. (1995) Religiosity and nationality: An exploratory study of their effect on consumer behavior in Japan and the United States. Journal of Business Research $34,1-9$.

Sousa, D. (1988) Tourism as a religious issue: A third world perspective. Contours 3 (5), 5-13.

Srisang, K. (1985) In search of a liberating discovery (I): Prologue to a theology of tourism. Contours 2 (3), 6-12.

Teo, P. and Huang, S. (1995) Tourism and heritage conservation in Singapore. Annals of Tourism Research 22 (3), 589-615.

Turner,V. (1973) The center out there: Pilgrim's goal. History of Religions 12 (3), 191-230.

Uriely, N., Israeli, A. and Reichel, A. (2000) Residents attitudes towards tourism events: The case of Nazareth 2000. In A.P. Russo (ed.) Proceedings of the Second International Seminar on Tourism Management in Heritage Cities (pp.99-116). Nazareth, 3-5 February.

Urry, J. (1990) The Tourist Gaze: Leisure and Travel in Contemporary Societies. London: Sage.

Urry, J. (1999) Gazing at history. In D. Boswell and J. Evans (eds) Representing the Nation: A Reader; Histories, Heritage and Museums (pp. 208-32). London: Routledge.

Walter, T. (2002) From cathedral to supermarket: Mourning, silence and solidarity. Sociological Review 49 (4), 494-511.

Waters, L.K., Batlis, N. and Waters, C.W. (1975) Protestant ethic attitudes among college students. Educational and Psychological Measurement 35, 447-50.

Wilkes, R.E. Burnett, J.J. and Howell, R.D. (1986) On the meaning and measurement of religiosity in consumer research. Academy of Marketing Science 14 (10), 47-56.

Worden, N. (2001) 'Where it all began': The representation of Malaysian heritage in Melaka. International Journal of Heritage Studies 7 (3), 199-218.

Zaichkowsky, J.L. and Sood, J.H. (1989) A global look at consumer involvement and use of products. International Marketing Review 6 (1), 20-34. 